\title{
Non-calculous Distension of the Gall-bladder in Childhood
}

\author{
R. A. BLOOM and VALENTINE A. J. SWAIN \\ From Queen Elizabeth Hospital for Children, Hackney Road, London, E.2
}

Gall-bladder disease is uncommon in childhood. In 1928 Potter collected reports of 226 cases of biliary disease in young subjects and a further 206 cases in the next decade (Potter, 1938). Ulin, Nosal, and Martin (1952) found another 43 cases reported between 1938-1948, but of the 475 cases so described he could accept only 326 as being authentic. Of the 30 cases of authentic gall-bladder disease reviewed by Ulin et al., only one was of acute non-calculous distension, namely that by Narat (1940). Two similar cases had been previously reported in 1933 by Fèvre and we have found another 18 recorded cases. The salient features of all these are tabulated (Table).

We here add 5 further cases to the 21 previously reported.

\section{Case Reports}

Case 1. R.B., a 5-year-old white boy, was admitted with a two-day history of intermittent abdominal pain and vomiting. On admission he was noted to be restless. Temperature $36^{\circ} \mathrm{C}$. $\left(96 \cdot 8^{\circ} \mathrm{F}\right.$.) ; pulse $92 / \mathrm{min}$., respiratory rate $20 / \mathrm{min}$. There was vague tenderness and muscle guarding on the right side of the abdomen in the region of the umbilicus.

The pre-operative diagnosis was a probable appendix abscess.

At operation a very tense and dilated gall-bladder presented; the common bile-duct was surrounded by two large lymph nodes which appeared to be obstructing the cystic duct. There was mesenteric lymphadenitis of fairly advanced degree, and one of the nodes was taken for histological examination. At cholecystostomy green bile was obtained and no stones were felt. The tube in the gall-bladder was left in place for $\mathbf{8}$ days, having drained approximately $10 \mathrm{ml}$. green bile daily. Apart from a post-operative chest infection there were no complications.

Three months later, a cholecystogram showed a normal-shaped gall-bladder which concentrated moderately well. There was no evidence of the presence of stones.

Received January 5, 1965.
The histological examination of the mesenteric lymph node exhibited non-specific reactive hyperplasia.

Case 2. R.T., a 5-year-old white boy, was admitted with a one-week history of sore throat, enlarged cervical lymph nodes, and headache. He developed a slight red blotchy rash on the face and extremities 3 days later and become anorexic. $\mathrm{He}$ was treated with penicillin at that time. The next day he developed pain in the right iliac fossa, which gradually intensified. This was accompanied by vomiting. He had three loose brown stools on the day of admission.

On examination he was noted to be pale with a dry mouth and lips. Temperature $36 \cdot 7^{\circ} \mathrm{C}$. $\left(98^{\circ} \mathrm{F}\right.$.); pulse $90 / \mathrm{min}$.; respiratory rate $20 / \mathrm{min}$. There was extreme muscle guarding and tenderness in the right iliac fossa. The pre-operative diagnosis was acute appendicitis.

At operation under anaesthesia a mass was felt in the right upper quadrant of the abdomen. On opening the abdomen a tense large cystic gall-bladder presented. Much green bile was aspirated but no stones were felt in the gall-bladder. The appendix appeared normal.

He made an uneventful post-operative recovery.

The following investigations were performed: Widal, negative; urine, normal; culture of bile, few colonies of Staph. albus; straight radiograph of abdomen, normal.

A cholecystogram one month after operation was reported: 'This appears to be a very large gall-bladder containing a large quantity of non-opaque material possibly "mud" in the lower third. The bile-duct outlines show no abnormalities.'

A further cholecystogram done one year later was normal.

He had remained well when seen two years later.

Case 3. J.P., a 26-month-old white boy was admitted with a five-day history of cough and nasal discharge treated with chlortetracycline. He appeared pale and was listless during this time.

On the morning of admission he had an attack of abdominal pain and extreme pallor which lasted a few minutes. Subsequently he had several further attacks that morning causing him to cry out with pain. His mother noted a threadworm in his stool. 


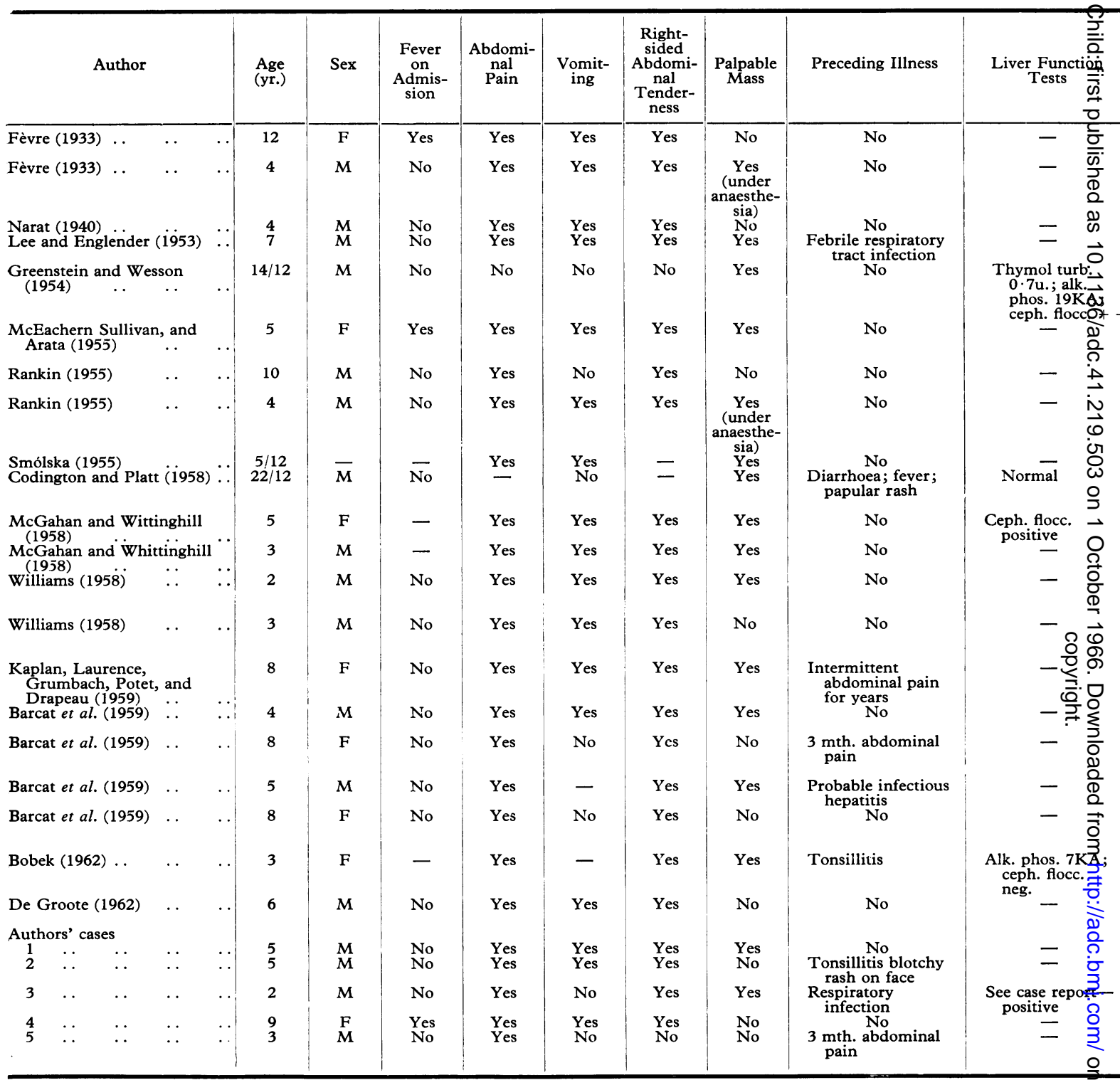

On admission he was pale but not obviously acutely ill. Temperature $36 \cdot 7^{\circ}$ C. $\left(98^{\circ} \mathrm{F}\right.$.) ; pulse rate $120 / \mathrm{min}$.; respiratory rate $26 / \mathrm{min}$. There was guarding and tenderness in the right upper quadrant of the abdomen, and a mass was felt.

Pre-operative diagnosis was an intussusception.

At operation under anaesthesia a slightly enlarged liver was felt above and continuous with the mass. On opening the abdomen a tense large sausage-shaped gallbladder presented, which was not inflamed, but a few enlarged lymph nodes were felt adjacent to the cystic duct. There was also generalized mesenteric adenitis of quite marked degree and the bile-ducts were oedematous. $60 \mathrm{ml}$. 'white bile' was aspirated from the gall-bladder; no stones were felt. The appendix was not inflamed. A cholecystostomy was performed.

A cholangiogram via the cholecystostomy tube on the third post-operative day showed free flow of the opaque medium from the gall-bladder to the duodenum. The cholecystostomy tube was removed on the sixth postoperative day, green bile having drained in decreasing amounts since operation. 


\begin{tabular}{|c|c|c|c|c|c|}
\hline $\begin{array}{l}\text { Bile from Gall-bladder at } \\
\text { Operation }\end{array}$ & $\begin{array}{l}\text { Pre-operative } \\
\text { Diagnosis }\end{array}$ & $\begin{array}{l}\text { Mesenteric } \\
\text { Adenitis }\end{array}$ & $\begin{array}{c}\text { Operation } \\
\text { on } \\
\text { Gall-bladder }\end{array}$ & Miscellaneous & Histology \\
\hline $\begin{array}{l}\text { Very dark; } \\
\text { culture-no growth } \\
\text { Clear yellow; } \\
\text { culture-no growth }\end{array}$ & $\begin{array}{l}\text { Cholecystitis or } \\
\text { retro-caecal app. } \\
\text { Appendicitis }\end{array}$ & Yes & $\begin{array}{l}\text { Aspiration } \\
\text { Aspiration }\end{array}$ & $\begin{array}{c}\text { Slight jaundice } \\
-\end{array}$ & - \\
\hline $\begin{array}{l}\text { White; few leucocytes } \\
\text { White } \\
\text { Turbid brown; } \\
\text { culture-no growth }\end{array}$ & $\begin{array}{c}\text { 二 } \\
\text { Hepatoma of liver }\end{array}$ & $\begin{array}{l}\text { No } \\
\text { Yes }\end{array}$ & $\begin{array}{l}\text { Aspiration } \\
\text { Removal } \\
\text { Removal }\end{array}$ & $\begin{array}{l}\text { Treated for ascariasis } \\
1 \mathrm{mth} \text {. previously }\end{array}$ & $\begin{array}{l}\text { Normal mucosa; cellular } \\
\text { infiltration of wall } \\
\text { Ring of fibrous tissue in } \\
\text { cystic duct; fibrotic walls }\end{array}$ \\
\hline $\begin{array}{l}\text { Dark green; } \\
\text { culture-no growth } \\
\text { Dark green }\end{array}$ & $\begin{array}{l}\text { Appendicitis } \\
\text { Intussusception }\end{array}$ & $\begin{array}{l}\text { Yes } \\
\text { Yes }\end{array}$ & $\begin{array}{l}\text { Removal } \\
\text { Drainage } \\
\text { Drainage }\end{array}$ & $\begin{array}{l}\text { Very anaemic } \\
\text { Threadworm infestation } \\
\text { - }\end{array}$ & $\begin{array}{l}\text { Fibrosis of walls; vascular } \\
\text { congestion; round cell } \\
\text { infiltration } \\
-\end{array}$ \\
\hline $\begin{array}{l}\text { Dark green } \\
\text { White }\end{array}$ & $\begin{array}{l}\text { Intussusception } \\
\text { Renal mass }\end{array}$ & 二 & $\underset{\text { Removal }}{\text { Aspiration }}$ & $\begin{array}{l}\text { Hepatomegaly } \\
\text { Very anaemic }\end{array}$ & $\begin{array}{l}\text { Walls of cystic duct thickened } \\
\text { with almost obliterated } \\
\text { lumen } \\
\text { Oedema and fibrous thickening }\end{array}$ \\
\hline $\begin{array}{l}\text { White; } \\
\text { culture-no growth } \\
\text { Bile-stained mucus }\end{array}$ & $\begin{array}{l}\text { gall-bladder } \\
\text { Hydrops of } \\
\text { gall-bladder }\end{array}$ & $\begin{array}{l}\text { Yes } \\
\text { Yes }\end{array}$ & Removal & $\begin{array}{l}\text { Lymph node histology } \\
\text { - no abnormality }\end{array}$ & $\begin{array}{l}\text { of walls; cellular infiltration } \\
\text { Oedema and fibrous thickening } \\
\text { of walls; cellular infiltration } \\
\text { Hypoplastic hepatic and } \\
\text { common bile-ducts; atresia } \\
\text { of cystic duct }\end{array}$ \\
\hline White & - & - & Removal & Fibrocystic disease & $\begin{array}{l}\text { Congested oedematous walls; } \\
\text { areas of infarction with } \\
\text { fibrinoid necrosis }\end{array}$ \\
\hline $\begin{array}{l}\text { White; } \\
\text { culture-coliforms }\end{array}$ & $\begin{array}{l}\text { Hydrops of } \\
\text { gall-bladder }\end{array}$ & Yes & Removal & Ascariasis & $\begin{array}{l}\text { Atresia of cystic duct; } \\
\text { metaplasia of epithelium }\end{array}$ \\
\hline $\begin{array}{l}\text { White; } \\
\text { culture-no growth }\end{array}$ & Intussusception & - & Aspiration & 一 & - \\
\hline Bloody fluid & - & - & Drainage & $\begin{array}{l}\text { Post-op.—normal } \\
\text { cholecystogram; slight } \\
\text { jaundice }\end{array}$ & - \\
\hline $\begin{array}{l}\text { White; } \\
\text { culture-no growth }\end{array}$ & 一 & - & Drainage & - & - \\
\hline $\begin{array}{l}\text { Green; } \\
\text { culture-normal }\end{array}$ & - & Yes & $\begin{array}{l}\text { Removal } \\
\text { (operative }\end{array}$ & - & - \\
\hline White & Appendix abscess & 一 & Removal & 一 & $\begin{array}{l}\text { Oedema and fibrous thickening } \\
\text { of walls; cellular infiltration }\end{array}$ \\
\hline Green & $\begin{array}{l}\text { Appendicitis or } \\
\text { intussusception }\end{array}$ & Yes & Removal & Intolerance to fatty foods & Normal mucosa; not congested \\
\hline Green & Appendix abscess & Yes & Drainage & $\begin{array}{l}\text { Post-op. cholecystogram } \\
\text { normal }\end{array}$ & 一 \\
\hline $\begin{array}{l}\text { Green; culture-few } \\
\text { Staph. albus } \\
\text { White; }\end{array}$ & $\begin{array}{l}\text { Acute appendicitis } \\
\text { Intussusception }\end{array}$ & 一 & $\begin{array}{c}\text { Aspiration } \\
\text { Drainage }\end{array}$ & $\begin{array}{l}\text { Post-op. cholecystogram; } \\
\text { large gall-bladder } \\
\text { Threadworm infestation }\end{array}$ & - \\
\hline $\begin{array}{l}\text { culture-no growth } \\
\text { Green } \\
\text { None }\end{array}$ & Peritonitis & $\overline{\text { Yes }}$ & $\underset{\text { None }}{\text { Drainage }}$ & $\begin{array}{l}\text { Biliary peritonitis } \\
\text { Spontaneous cure }\end{array}$ & 二 \\
\hline
\end{tabular}

Apart from a mild chest infection the post-operative course was uneventful.

The following investigations were done:

'White bile' obtained at operation: alkaline fluid with no protein, leucocytes $15 / \mathrm{hpf}$; RBC $4 / \mathrm{hpf}$; culture-no growth.

10 days after operation: thymol turbidity $5 \mathrm{u}$; zinc sulphate turbidity $2 \frac{1}{2} \mathrm{u}$; ; $\alpha$-globulin turbidity $6 \mathrm{u}$.; SGPT 522 u.; SGOT 245 u.; Paul Bunnell test-negative. 6 weeks after operation: thymol turbidity $1 \mathrm{u}$; ; zinc sulphate turbidity $1 \frac{1}{2}$ u.; $\alpha$-globulin turbidity 5 u.; bilirubin $0.5 \mathrm{mg} . / 100 \mathrm{ml}$; alkaline phosphatase $40 \mathrm{KA}$.

One month after the child was discharged from the ward his brother presented in the Casualty Department with, clinically, infectious hepatitis. His liver function tests were: thymol turbidity $12 \mathrm{u}$.; thymol flocculation ++++ ; zinc sulphate turbidity 5 u.; $\alpha$-globulin turbidity $10 \mathrm{u}$.; bilirubin $3.3 \mathrm{mg}$. $/ 100 \mathrm{ml}$.; direct Van den Bergh-positive; alkaline phosphatase $40 \mathrm{KA}$; Paul Bunnell test-negative.

Case 4. C.M., a 9-year-old white girl, was admitted 
with a one-week history of vomiting and she had had upper abdominal pain for 3 days. She had complete anorexia and loose motions.

On admission her temperature was $37 \cdot 8^{\circ} \mathrm{C}$. $\left(100^{\circ} \mathrm{F}\right.$.); pulse $100 / \mathrm{min}$; respiratory rate $20 / \mathrm{min}$. Her tongue was furred and she had slight tenderness in the left hypochondrium. The next day she was in obvious pain with diffuse guarding of the abdomen: there was further vomiting.

At operation a large quantity of bile-stained fluid was found in the peritoneal cavity. The gall-bladder was whitish in colour and very tense. No stones could be felt in the biliary tract nor in the vicinity, and there was no visible perforation. The abdomen was drained and a cholecystostomy performed. The child made a slow but steady post-operative recovery.

The following investigations revealed urine, with no bile present; Hb $104 \%$; WBC; 18,300 , polymorphs $65 \%$. two days after operation: thymol turbidity $4 \mathrm{u}$.; bilirubin $1.5 \mathrm{mg} . / 100 \mathrm{ml}$. Liver biopsy taken at operation showed a normal histology.

Case 5. B.D., a 3-year-old white boy, was admitted with a history of frequent attacks of pain in the epigastrium over the previous three months. He had also had recurrent upper respiratory tract infections. The attacks of pain had become more frequent and recently had been occurring at least three times a day, each attack lasting about 10 minutes. He had been miserable and anorexic for the previous three days with more frequent attacks of pain.

On examination, his temperature was $36 \cdot 7^{\circ} \mathrm{C}$. $\left(98^{\circ} \mathrm{F}\right.$.); pulse $80 / \mathrm{min}$.; respiratory rate $20 / \mathrm{min}$.

In spite of the fact that there were no positive physical signs in the abdomen, a laparotomy seemed indicated by the history.

On opening the abdomen a large tense gall-bladder was noted, which emptied a little on pressure. No stones were felt in the biliary tract. There were many large mesenteric lymph nodes. The appendix, which appeared to be normal, was removed and the abdomen closed.

Post-operative recovery was uneventful until the eighth day when the abdominal wound burst open. The abdomen was repaired under general anaesthesia. At operation the gall-bladder was noted to be of normal size.

The recovery thereafter was uninterrupted.

\section{Discussion}

In each of the 21 previously reported cases as well as in our 5 cases, the only constant feature was marked distension, without obvious acute infection, of the gall-bladder. The absence of calculi at laparotomy has been obligatory for inclusion in this series. 23 out of the 26 cases presented as an acute illness in childhood with abdominal pain, right-sided abdominal tenderness, and usually accompanied by vomiting. The other 3 occurred in infancy and presented differently. The case described by
Greenstein and Wesson (1954) was a 14-month-old boy with a mass found on routine examination. Codington and Platt (1958) described an acute illness with fever, rash, and diarrhoea in a 22 -month-old child and a non-tender mass was palpated in the abdomen: in both of them cholecystectomy was performed; as anatomical obstruction to the cystic duct was demonstrated, these 2 cases seem to differ from the rest. Thirdly, Case 5 was a 3 -year-old boy who had marked abdominal pain but no obvious abdominal tenderness or vomiting.

Incidence. Acute distension of the gall-bladder is very uncommon, according to published reports. The condition occurs in both sexes with a mean age of 5 years: there were 8 girls, 17 boys, and one whose sex was unspecified. 25 were Caucasian children, and 1 was an American Indian.

Preceding illness. In 4 cases there was a history of a respiratory tract infection; 3 other children had suffered intermittent abdominal pain for months or years previously. A further child had previous gastro-enteritis, and the third case described by Barcat, Boissière, Aubert, and Gatelmand (1959) had almost certainly had previous infectious hepatitis.

Worm infestations were found in 3 children, threadworms in 2, and roundworms in 1.

Pathology. Cholecystectomy was the method of treatment in 11 of the children, and the gall-bladders were examined histologically. In most of the cases there was cellular infiltration with fibrosis of the walls. However, both these features are found to a greater or lesser extent in normal gall-bladders. Marked oedema of the walls was found in both of McGahan and Whittinghill's (1958) cases.

In 4 cases, however, there seemed to be anatomical obstruction to the flow of bile through the cystic duct (see Table) with obvious aetiological significance.

Clinical picture. Abdominal pain is present in almost all cases and is usually situated in the right upper quadrant of the abdomen, but may be in the midline or epigastrium. The pain may have a severe and sudden onset becoming continuous or increasing in intensity. In some instances the intermittent spasms of pain resemble those of acute intussusception.

The pain is almost always accompanied by vomiting or at least nausea. There is usually no fever. Slight jaundice has been noted in 2 cases (one of Fèvre's and one of Barcat et al.'s cases). In 22, 
there was right-sided abdominal tenderness, and a mass was palpated in the right upper quadrant in 16 of the 26 cases.

Pre-operative diagnosis. The almost invariable inaccuracy of pre-operative diagnosis seems to be due to the rarity of gall-bladder disease in children and failure to consider the possibility of its existence in a child with abdominal pain. Such cases are often wrongly diagnosed as acute appendicitis or intussusception.

Aetiology. This is not known. A number of different suggestions have been made, but there is no reason to insist on a single cause for all cases. Those described by Lee and Englender (1953), Greenstein and Wesson (1954), and Codington and Platt (1958) in which there was complete or almost complete atresia of the cystic duct with signs of chronic inflammation suggest previous acute cholecystitis with fibrosis. In one of the cases described by Williams there was a hypoplastic biliary tract and the atresia of the cystic duct here seems to be due to a congenital malformation, possibly complicated by infection.

In the large majority of cases there has been no anatomical blockage of the cystic duct, and the spontaneous re-establishment of bile flow after aspiration or temporary cholecystostomy confirms a purely temporary condition.

Cholangitis in the region of the cystic duct seems most likely to be the cause, as suggested by Narat (1940). Lee and Englender (1953) remarked that the inflammatory obstruction of the narrow cystic duct might be augmented by an impinging lymph node.

Thus it is significant that in 13 of the 26 recorded cases, marked generalized mesenteric adenitis was specifically mentioned, and in many of these the cystic lymph node was stated to be very large. While actual mechanical obstruction by this node seems unlikely, this inflamed gland may well cause a reactive inflammation of the cystic duct by its close proximity.

The cause of the mesenteric adenitis and cholangitis has hitherto been obscure. McGahan and Whittinghill (1958) described 2 patients who had been in contact with infectious hepatitis. 2 others had slight jaundice, one other had hepatomegaly and another 2 had abnormal liver function tests. A case of Barcat et al. (1959) had previous probable infectious hepatitis. Our Case 3 had very abnormal liver function tests a few days after the operation. This finding in conjunction with hepatomegaly noted at operation made us suspect acholuric infectious hepatitis. The development of infectious hepatitis by the patient's brother shortly afterwards supports this suspicion.

On the basis of all these facts we suggest the aetiology of the condition, at least in some of the cases, to be the virus of infectious hepatitis.

Treatment. Half the cases were treated by aspiration or drainage, and all made good recoveries without complications. Our Case 5 made a spontaneous recovery without any interference with the gall-bladder.

Simple aspiration of the gall-bladder appears to be the treatment of choice as this is less likely to introduce infection. If anatomical obstruction to the cystic duct appears likely, we suggest the establishment of a cholecystostomy, whereby performance of a post-operative cholangiogram would demonstrate the patency or otherwise of the biliary ducts. Cholecystectomy can always be done on the basis of the cholangiogram findings, as a secondary procedure. We can find no indication for cholecystectomy as a primary procedure in this condition.

In spite of the fact that the condition can spontaneously resolve, as occurred in Case 5 , we suggest that aspiration is necessary to relieve pressure in tensely distended gall-bladders, lest perforation and biliary peritonitis result, as in our Case 4 . However, even if this does occur peritoneal drainage and cholecystostomy seems adequate. Perforation in this condition is distinct from bile-duct perforation in infancy, which occurs within the first few weeks of life, and where perforation of the bile-duct is probably due to its blockage by inspissated biliary mud, with or without hepatic disease.

\section{Summary}

Five cases of non-calculous distension of the gall-bladder in childhood are described, and 21 other recorded cases reviewed.

It is suggested that the aetiology of some of the cases is a transient inflammation of the cystic duct associated with mesenteric lymphadenitis caused by the virus of infectious hepatitis. In other cases scarring following previous acute cholecystitis is suggested.

Simple aspiration of the gall-bladder is effective in most instances, but if anatomical obstruction is suspected cholecystostomy enables the performance of post-operative cholangiography with accurate visualization of the biliary tract.

We should like to thank Mr. G. Stead for permission to include Case 1 in this paper.

\section{REFERENCES}

Barcat, J., Boissière, H., Aubert, J. P., and Gatelmand, R. (1959). Les cholécystites aiguës chez l'enfant. Presse méd., 67, 645. 
Bobek, D. W. (1962). Hydrops of the gallbladder in a 3-year-old girl. F. Okla. med. Ass., 55, 125.

Codington, J. B., and Platt, M. S. (1958). Hydrops of the gallbladder in an infant. Sth. med. F. (Bgham, Ala.), 51, 1529.

De Groote, C. (1962). Les distensions vésiculaires aiguës chez l'enfant; leur place parmi les dyskinésies cervico-cystiques. Ann. Chir. infant, 3, 185.

Fèvre, M. (1933). Distensions vésiculaires douloureuses aiguës et subaiguës chez l'enfant. Bull. Soc. Pédiat. Paris, 31, 391.

Greenstein, N. M., and Wesson, H. (1954). Hydrops of the gallbladder in a 14-month-old infant. Amer. F. Dis. Child., 87, 208.

Kaplan, M., Laurence, G., Grumbach, R., Potet, F., and Drapeau, P. (1959). Hydrocholécyste avec malformation du cystique et du cholédoque chez une enfant de 8 ans. Arch. frans. Pédiat., 16, 373.

Lee, C. M., Jr., and Englender, G. S. (1953). Massive hydrops of the gallbladder producing pyloric obstruction in a 7-year-old boy. Pediatrics, 11, 449.
McEachern, C. G., Sullivan, R. E., and Arata, J. E. (1955). Massive hydrops of the gallbladder in a 5-year-old girl. Ann. Surg., 142, 1038.

McGahan, J. J., and Whittinghill, J. A. (1958). Acute idiopathic hydrops of the gallbladder not due to calculi, possibly to infectious hepatitis. Pediatrics, 21, 91.

Narat, J. K. (1940). Hydrops of gall-bladder in a 4-year-old child. Amer. F. Surg., 49, 513

Potter, A. H. (1928). Gall-bladder disease in young subjects. Surg. Gynec. Obstet., 46, 795.

- (1938). Biliary disease in young subjects. ibid., 66, 604.

Rankin, W. (1955). Acute distension of the gall bladder in children. Arch. Dis. Childh., 30, 60.

Smólska, I. (1955). A case of gall bladder ectasis in an infant. (In Polish.) Pediat. pol., 30, 1085.

Ulin, A. W., Nosal, J. L., and Martin, W. L. (1952). Cholecystitis in childhood: associated obstructive jaundice. Surgery, 31, 312. Williams, R. J. (1958). Acquired mucocele of the gall-bladder in childhood. Brit. med. f., 3, 1047. 